\title{
The Genesis of a Poem
}

\author{
K.E. Bugge
}

It is well known that Grundtvig's poem about Christ's Descent into Hell was published for the first time in his comprehensive collection of hymns, Sang-Vark til den Danske Kirke (1837). But the question of genesis remains: When was the poem written? The question of when is, however, closely connected with the question of why. In other words, what understanding of the Descent theme did Grundtvig have from his early years? Is it possible to identify additional, later sources of his inspiration? Of what importance is it that for a number of years he was a preacher and that during the 1830s he may very well have had occasion to preach about Christ's Descent into Hell? The following facts are well established: (1) the poem is fundamentally inspired by Anglo-Saxon sources, (2) from 1828 onwards, Grundtvig's friend the Rev. Gunni Busck prompted him to publish a collection of hymns, and (3) Grundtvig embarked on this task in 1835, but that the main substance of the Sang-Verk was written in 1836 (cf. Balslev-Clausen, 52-66). It has, therefore, been deemed unnecessary to repeat these facts in the following exposition.

\section{Early encounters}

During his childhood and adolescence, Grundtvig encountered the theme of Christ's Descent in a variety of contexts. The theme arises in the Apostles' Creed, which was professed at baptisms and, according to prescripts from 1537, the pastor was bound by duty to quote the following verses from 1 Peter 3:18-22 at the beginning of the service on Quinquagesima Sunday:

For Christ also hath once suffered for sins, the just for the unjust, that he might bring us to God, being put to death in the flesh, but 
quickened by the Spirit: By which also he went and preached unto the spirits in prison; which sometime were disobedient, when once the longsuffering of God waited in the days of Noah, while the ark was being prepared, wherein few, that is eight souls, were saved by water. The like figure whereunto even baptism doth also now save us (not putting away of the filth of the flesh, but the answer of a good conscience toward God,) by the resurrection of Jesus Christ: Who is gone into heaven, and is on the right hand of God; angels and authorities and powers being made subject unto him (King James Version). ${ }^{1}$

In the ancient church, some theologians had already understood the message concerning Christ preaching "unto the spirits in prison" as a "proof" (dictum probationis) of Christ's Descent into Hell. Furthermore, the hymns to be sung on each Sunday were prescribed, and on Quinquagesima Sunday a hymn by Thomas Kingo, the highly esteemed bishop and hymn-writer from the Baroque period, was assigned. In this hymn Kingo develops the Descent-theme in two 8-lined verses. Grundtvig likely knew this hymn and, more significantly, the extensive treatment his father, Johan Grundtvig, gave the theme in his book of catechetical instruction, which was titled Catechismi Forklaring [Catechetical Elucidation, 1779]. Four paragraphs (\$\$245-248) deal with the Descent theme, and the relevant scripture-texts are quoted. We know that Johan Grundtvig presented the book to his son in 1791 and that he used it during preparation for confirmation in 1798.

Although Grundtvig acquired some knowledge about the Descent by virtue of this background, we have no evidence suggesting that it made any

1 [v. 18] Thi og Christus (selv) leed eengang for Syndere: Den Retfærdige for de Uretfærdige, paa det hand (derved) maattet føre os til GUD, hand, som blev dødgiort (efter) Kiødet, men levendegiort (efter) Aanden. [v. 19] I hvilken hand og gik bort og prædikede for Aanderne, (som vare) i Fængselet, [v. 20]. Hvilke fordum ikke troede, der Guds Langmodighed tøvede engang udi Noe Tid, da Arken (imidlertid) blev bereed, i hvilken faa, det er otte Siæle, bleve frelste i Vandet. [v. 21].Til hvilket og Daaben nu svarer, som giør os salige: Ikke den U-reenligheds Borttagelse paa Kiødet, men en god Samvittigheds Pagt med GUD formedelst Jesu Christi Opstandelse, [v. 22]. Hvilken, efter at hand er opfaren i Himmelen, er (nu) hos Guds høyre Haand, hvor Englene og de Vældige, og Kræfterne ere hannem underdanige (Forordnet Alter-Bog udi Danmark og Norge, 48-49). 
particular impression on him. In 1798-1800, when he attended Grammar School [Latinskolen] in Aarhus, the teaching of the subject "Theology" was based on a textbook that discussed the Descent theme in only a single paragraph. This notable brevity is in accordance with the thinking of the Age of Enlightenment when the concept of Hell was thought ridiculous.

\section{Student of theology}

Grundtvig studied theology at the University of Copenhagen during the years 1800-1803. In the present context, it is relevant to consider his diaries, specifically what he writes about his studies in the fields of church history and dogmatics. In September 1802, he mentions that he has studied "a bit of dogmatics" [en Slump Dogmatik]. Much more eloquent are his notes on his final examinations, where we learn that the history of the creeds, which is the subject area where church history and dogmatics overlap, has caught his interest. In this field he may very well have encountered the Descent theme. But where? He severely criticizes most of the textbooks he mentions; he gives only one, Fuldstendig Kirkehistorie [Complete Church-History] by N.D. Riegels (I-III 1781-86), a moderately positive evaluation. But the book does not mention the Descent theme, not even in contexts where it could be expected, for example, in the sections dealing with the life of Jesus or with Christological controversies. He gives his only unambiguous praise to "a compendium of the history of dogmatics" [et Kompendium af Dogmehistorien] which saved his performance at the written examination, where he was asked to "describe the ancient theologians' ideas on the resurrection of Christ from the dead" [Exponatur veterum Xstianorum sententiæ de a Xst: e inferis]. ${ }^{2}$ In his notes about his final examinations, Grundtvig describes his performance as follows:

I began by delineating the notions, which Jews and pagans brought with them, when they became Christians, about Sheol and Orcus. In this way I prepared my way into the ideas of the Fathers. My memory

2 In those days examinations were conducted in Latin. "E inferis," i.e. from the lower areas," has been translated in various ways: from the grave, from Hell, and generally from the dead. 
served me so well that I was able to quote the statements, which I had read in my compendium. This must have given the professor a highly positive conviction about my erudition in the field of history of dogmatics. - I wrote five full pages. ${ }^{3}$

Here Grundtvig moves into close proximity of the Descent theme. That this theme is not mentioned in his account may be attributed to the fact that, at that time, the topic was held in low esteem and little debated. Another explanation may be that his compendium did not offer any relevant quotations.

\section{Vicar, historian and philologist}

Grundtvig, it seems, had no occasion to reflect upon the Descent theme between 1803-11, nor does it seem that he thought about it between 181113 , when he was regularly working as a clergyman after having been appointed to assist his ageing father as vicar in Udby. He does not treat the theme in his Bibelske Predikener [Biblical Sermons] printed 1816 or in his unpublished sermons on Quinquagesima Sunday and Ascension Day. Furthermore, Grundtvig's extensive poem Paaske-Lilien [The Easter-Lily] from 1817 does not mention the Descent in connection with the Easter events. When the poem declares that "the dragon is chained" (DV II, 317), it is not referring to the Devil, but to death as such, which is expressly mentioned in the quotation from I Cor 15:55 that follows the passage.

Between 1810 and 1820, Grundtvig published three sizeable universal histories in 1812, 1814, and 1817. In the publication from 1812, he briefly described the life of Jesus but he does not mention the Descent. In the volume from 1814, he treats only the historical events up until and including the Book of Daniel in the Old Testament. In the volume from 1817,

3 Ieg begyndte med at vise hvilke Meninger Iøder og Hedninger bragte med sig da de bleve Kristne om שאול og Orcus og saaledes beredte Ieg Veien for mig til at fremstille Fædrenes Meninger, og min Hukommelse var mig saa tro at Ieg verbotenus kunde anførte Citater af Kirkefædrene som Ieg i mit Kompendium havde seet - Dette tænker leg især har - uforskyldt - givet Hr. Professor Mynter en høie Idee om mine Dogmehistoriske Kundskaber - Ieg skrev herover 5 Qvartsider (Grundtvig 1979, (I) 40-41). 
the description of the life of Jesus appears as a repetition of the earlier account from 1812. His narration about England is, however, considerably enlarged in comparison with the earlier book. In 1817, he describes the Anglo-Saxons as "one of the most remarkable people of Christendom" [et af Christenhedens mærkeligste Folk] (VK 1817, 81). This is evident, because a scholar such as Bede, a poet such as Cædmon, a king such as Alfred and a literature such as that of which - in Bede's Ecclesiastical History, in the Biblical paraphrase [i.e. in the poetical works of Cædmon], in the great heroic poem about the Goth Beowulf and in much still unknown - we have fragments, we seek in vain in those centuries, except in the Angles' Island. ${ }^{4}$

The inspiration behind this eloquent and positive evaluation was Grundtvig's intensive Anglo-Saxon studies begun in 1815 and pursued on and off - for the rest of his life.

In 1817 in the second volume of his periodical Danne-Virke ${ }^{5}$, we find a more extensive presentation of Cædmon's "Paraphrase," i.e. a poetical narrative covering the biblical story from the beginning until and including the Ascension of Christ. The poem is characterized as "a colossal epic vision" [et kolossalt episk Syn]. Negatively, Grundtvig adds that the poet "with a bizarre participation has treated the self-made scene in Hell" [med besynderlig Deeltagelse har dvælet ved det selvgjorte Optrin i Helvede] (DV II, 277).

Some critical remarks on the Paraphrase appear also in the following volume of the periodical, where Grundtvig describes a vision in which the spirits of Caedmon and Luther meet. At this fictive occasion, Luther voices the opinion that God has not tuned Cædmon's harp (DVIII, 343). At this juncture Grundtvig has obviously nourished an ambiguous attitude towards Cædmon's paraphrase; he admires Cædmon's poetical vision, but he negatively observes that Cædmon's description of the Descent is self-made [selvgjort], in other words, that its biblical foundation is dubitable. These negative remarks are most likely inspired by Grundtvig's person-

4 ...en lærd som Beda, en Skjald som Cædmon, en Konge som Alfred, og en Literatur som den, hvoraf vi i Bedas Kirkehistorie, i den bibelske Paraphras [dvs. i Cædmons poetiske værk], i det store Heltedigt om Gothen Bjovulf, og i Meget endnu Ubekjendt have Brudstykker, søge vi i hine Aarhundreder forgjæves undtagen paa Anglernes Øe (VK 1817, 81).

5 The name of the periodical, Danne-Virke, alludes to the southern ancient frontier of the kingdom of Denmark, cf. Bradley (2008), 396-397. 
al involvement in the celebrations of the 300 years' jubilee of the Lutheran reformation, which took place in 1817. For this occasion Grundtvig published not only the above quoted History of the World primarily in the Lutheran Era (675 pages) but also translated a number of Luther-hymns.

\section{Decisive Irenaeus-inspiration}

About 1820 Grundtvig's attitude towards the Descent theme had developed from an early, superficial and indifferent knowledge to an ambiguous - as it seems mainly negative - appraisal gained during his studies after 1815. In the 1820s his attitude changes and becomes positive. From 1821 onwards Grundtvig worked full-time, first as a vicar in Præstø then as a curate in Copenhagen, an occupation which provided regular occasions to preach upon the First Epistle of Peter, chapter 3, where the Descent of Christ is mentioned. The first traces of a new development in his attitude are found in an Evensong-sermon from 1823, where he deals in some detail with the question, whether the Bible "explicitly describes such a Descent." He admits that one might speak of "a spiritual act" in which our Saviour visited a prison for the unbelieving dead, and where he preached the word of faith unto the inmates. Nevertheless, he points out that the event did not occur in any "physical location." It is important, he continues, that "this narrative is so short and so obscure that the apostles would not impose it upon us." The following year he mentions the text from the First Epistle of Peter, but he does not develop its importance. On Quinquagesima Sunday he chooses to preach on the topic of baptism. To do so was not only prescribed for the morning service on the baptism of Jesus (Matt 3); it was also an obvious possibility considering that the text from the First Epistle of Peter, which was to be used at the Evensong-service, mentions that some were "saved by water" (Thodberg 1983, I. 143-5). In other words Grundtvig is here notably silent on the subject of the Descent.

The next year, in 1825, a significant development unmistakably took place in Grundtvig's thinking about the Descent theme. In the Evensongsermon on Quinquagesima Sunday, Grundtvig once again returns to the text in the third chapter of the First Epistle of Peter. He points out that for non-believers the tale of Christ's Descent into Hell is only "a heap of nonsense"; for the believers - in contrast - this story is a shining light 
showing us the road from "the vale of death" to "the land of the living." He claims that when the text refers to Noah and salvation "by water" it is to be understood "in the light of the revelation through Christ." It should then be obvious, he says, that that he "descended into the waves of death in order to save all those, who drew near to him." And still, in our days, the ship of the church, the ark of the Lord, commands the deep waters (Thodberg 1983, III. 92-100).

During the year 1824-25 Grundtvig's attitude towards the Descent theme developed further, this time due to his intensive studies of the works of Irenaeus (died c. A.D. 200), one of the ancient so-called Church Fathers. These studies were carried through from and after 1822, and a few years later Grundtvig translated one of the major works of Irenaeus. Grundtvig's theological controversies concerning the Apostles' Creed during the years from 1825 and onwards sustained and invigorated this development.

Grundtvig's Irenaeus-translation appeared in volume XI of the periodical Theologisk Maanedsskrift [Theological Monthly] 1827 under the title "On the Resurrection of the Body and Participation in the Kingdom of God. The Fifth Book of Irenaeus" [Om Legemets Opstandelse og Deel $i$ Guds Rige. Irenai 5te Bog]. At the end of the translation the following comment is inserted in a footnote:

Irenaeus not only comments on the Descent of our Lord into Hell (Hades) with definite certainty; he also presupposes that the heretics are well aware of this, (...) as they accuse the church of Christ of having falsified the original Creed by some time during the second century having smuggled the Descent into the Creed. ${ }^{6}$

Clearly, his encounter with the opinions of Irenaeus fortified both his knowledge of the history of the Descent clause in the Creed and his readiness to defend it on his own account. The main theme of Grundtvig's contributions to the periodical during the following years was the court

6 Irenæus ikke blot omtaler Herrens Nedfart til Helvede (Hades) som en afgjort Sag, men forudsætter den indrømmet selv hos Kjætterne, (...) da [de] beskylde Christi Menighed for at have forfalsket den oprindelige Troes-Bekiendelse, ved engang i det andet Aarhundrede at indsmugle Nedfarten til Helvede deri (Grundtvig $1827,255)$. On Grundtvig's studies of Irenaeus, see Bradley $(2008,465)$, Thaning (1963) and Schjørring (1990). 
decision of 1825 imposing censorship of his publications.7 Indirectly related to these controversies is, for example, the publication of Christelige Predikener [Christian Sermons] I-III in the eighteen-twenties (1827-30).

\section{Visits to England 1829-31}

Several years had elapsed since Grundtvig's first encounter with AngloSaxon literature in 1815. That he had not forgotten Cædmon is nevertheless evidenced in his Krønike-Riim til Børnelardom [Historical rhymes for the education of children] 1829, where he writes:

Cædmon var en Kirke-Skjald Kongelig i Aanden, Davids-Harpen sært ham faldt

Drømmende i Haanden. Toned høit om Paradis Toned til Jehovas Priis Prægtig i det Hele. (Grundtvig 1829, 59-60)
Cædmon was an ecclesiastical bard of royal spirit.

In a marvellous way the harp of

David was

handed to him, while he dreamed. Euphoniously he sang about Paradise and praised Jehova wondrously through and through

In the very same year, 1829, Grundtvig received a royal grant, enabling him to continue his Anglo-Saxon studies through three trips to England in 1829, 1830 and 1831 . In the present context we shall concentrate on Grundtvig's second encounter with Cædmon. During his second trip Grundtvig visited the Bodleian Library in Oxford. ${ }^{8}$ Here he transcribed the Anglo-Saxon text of Cædmon's Paraphrase from the famous Junius-manuscript and translated the first 18 lines thereof into Danish. ${ }^{9}$ The Paraphrase contains an extensive treatment of the Descent theme. An important source, that in this respect is assumed to have inspired the

\footnotetext{
7 Concerning this controversy, see Thyssen (1983, 226-234); Allchin (1997, chap. 6) and Bradley (2008, 383 and 475).

8 Concerning his studies of other manuscripts and his negotiations with British philologists it must here suffice to refer to the pertaining literature, especially the writings of Allchin (1997, ch. 3) and Bradley (1996).

9 For information about the Junius manuscript, see Bradley (1982, 97-105).
} 
Anglo-Saxon poet, is the apocryphal "Gospel of Nicodemus." Grundtvig's own edition of this gospel was J.A. Fabricius's Codex apocryphus Novi Testamenti I-III (Hamburg 1719). Should he have forgotten, then he was reminded of the book's existence by reading Thomas Warton's History of English Poetry (1821), which he bought in 1829. The third volume of Codex apocryphus brings an account of the English literature inspired by the Nicodemus-gospel (Toldberg 1947, 273). Furthermore, in his diary Grundtvig mentions that in the same year he bought Peter King's History of the Apostles' Creed (1703) - an acquisition that reflects his early interest in the history of dogmatics.

On the background of Grundtvig's new, positive appraisal of the Descent theme attained in the 1820s and considering the manifold inspiration he gained in England, one could have expected that after his return to Denmark he would immediately have engaged himself in a renewed drive towards rectifying the general negative opinion of this section of the Creed. But that did not happen. Why not? It was no trivial matter. Had he not publicly stated that the Descent of Christ into Hell bore witness to a passage from "the vale of death" to "the land of the living"?

\section{New commitments}

The Grundtvig-biographer F. Rønning has declared that in the 1830s Grundtvig did not spend much of his time on Anglo-Saxon studies (Rønning 1885,157$)$. On the face of it, this seems to be true. Immediately after his return to Denmark, Grundtvig began writing his Nordens $M y$ thologi [The Mythology of the North] (1832). Even though he includes the Anglo-Saxons in his concept of Nordic people, he mentions Cædmon only once briefly. Grundtvig engaged himself in other matters of interest. In the same year, in co-operation with the young student L.C. Hagen, he published the small but important collection of Historiske Psalmer og Riim til Børne-Lardom [Historical Hymns and Rhymes for the Education of Children]. Soon after he began working on his Haandbog $i$ VerdensHistorien [Hand-Book in the History of the World], of which the first volume was published in 1834 and the second in 1836. In 1835 he initiated the collection of hymns, and saw the first two instalments appear in October and December 1836 and the completed volume in 1837. In between 
he closely observed contemporary political developments. The notable advance of liberal ideas might pave the way not only for him personally in an annulment of the censorship that had been imposed on him in 1825 . It might also further ideas concerning new relations between church and state, which he had outlined in his book Den Danske Stats-Kirke upartisk betragtet [The Danish State-Church Impartially Regarded] 1834. Finally, from 1836 onwards, he began publishing a series of books advocating his new ideas on adult education, and in his spare time he wrote hundreds of letters. This was in an era without telephone and electronic communication. To some of his closest friends he wrote letters more than once a week.

In view of all these demanding activities, there was evidently little or no time for the pursuit of Anglo-Saxon studies, or, more specifically, for advocating positive attitudes to the Descent theme. Nevertheless, it remains puzzling that he did not involve himself in those matters. During these years there were actually several incentives to do so. First, it is a fact that the Cædmon-Paraphrase, which he had studied in Oxford, had made a deep impression on him. Second, not only did he own two copies of Benjamin Thorpe's edition of the text published in 1832, a year after he returned to Denmark but, as pointed out by Toldberg (1947, 275), he also spent time checking and amending not only Thorpe's edition but also his own transcription. And third, during the 1830s Grundtvig was for many different reasons constantly reminded of the Descent theme. In other words, he was not allowed to forget it. We shall now direct our attention to the events in his personal life that likely focused his attention on the Descent theme.

\section{The situation}

Until his appointment as pastor of the congregation at Vartov in 1839, Grundtvig's personal situation was in several respects insecure. As a consequence of the libel suit and the censorship imposed on him, Grundtvig had resigned from the ministry in May 1826 and from then on was without regular pastoral income. Since 1818, however, he had retained a limited official stipend in recognition of his historical and philological achievements, but his income from publications was irregular and insufficient. In these contexts his publication of a "World History" may be seen as an effort to attain the qualification necessary for obtaining an appoint- 
ment as a professor of history either at the University of Copenhagen or at the Academy at Sorø. In a letter from July 1830 written from England to his wife, he mentions that "at present tenure as professor of history is the employment I desire" [ At den historiske Lærestol er den Plads, jeg for Øieblikket ønskede] (Grundtvig 1920, 116).

In addition to these worries Grundtvig had to manoeuvre carefully in a political situation characterized by numerous bitter controversies. A critical situation had emerged regarding the relations between the official secular and ecclesiastical authorities, on the one hand, and a religious lay movement called the "godly assemblies," on the other. These layfolk often accused the clergy of not respecting the Holy Bible and the ordinances regulating the administration of the sacraments. They usually chose not to meet in churches but in private homes, where they studied the holy scripture, listened to lay preachers, and sang hymns of their own preference. As a result of their obstinacy, they became involved in numerous court-cases that ended with fines or imprisonment.

For a number of reasons, these groups generally regarded Grundtvig with sympathy. In an article from the mid-eighteen-twenties, he had publicly defended their right to assemble in order to praise God, even though he had some reservations about some of their views. In 1826, he had left the state-church, and he had preached a few times at their assemblies. Most favourable to them was that the brilliant orientalist Jacob Christian Lindberg ardently and incessantly defended Grundtvig against all his critics. Lindberg was well-known and highly respected among the people of the "godly assemblies." Through the foregoing decade, he had in numerous writings defended the revivalists and had publicly supported them in their court-cases. Furthermore, he had by frequent and extensive travelling all over the country not only gained an intimate knowledge of the movement and its problems, but he had also formed a personal link between the many different segments of the movement. From 1833 and onwards Lindberg published the weekly paper Nordisk Kirke-Tidende [Nordic Church-News]. Grundtvig became a frequent contributor to this paper.

Through his close ties to Lindberg and his weekly paper, Grundtvig became well aware of the eventuality of being identified with the movement. He certainly knew that he might be considered a "revolutionary" outsider and thus forfeit his chances of obtaining an official appointment for example as a professor of history. On the other hand, he may have also 
become aware of the political potential of the movement, which might in the future provide a basis for a new ecclesiastical structure in which he could regain an appointment as a pastor. In the present context, it is finally important to notice the fact that the Descent theme was often and energetically debated in Nordisk Kirke-Tidende. We shall now trail that particular debate, as it developed year by year in this weekly journal.

\section{$1831-32$}

By 1831 Lindberg had already begun to attack the rationalistic clergyman C. H. Visby, accusing him of denying in one of his sermons the possibility of eternal damnation and the possibility of conversion after death. For the revivalists such a stance was entirely unacceptable, as it drastically reduced the importance of a conversion during one's lifetime. During the ensuing court-case, Lindberg additionally accused Visby for contempt of $\$ 17$ in the Confessio Augustana, one of the basic creeds of the Danish Lutheran church. In this paragraph it is expressly stated that "Christ will condemn the ungodly and devils to eternal damnation." Nevertheless, the defence won the case arguing that Visby had not violated the paragraph as such; he had only voiced a certain interpretation thereof.

The Visby Case may be seen as an overture to the following year's debate. Not only did the official teachings of the church come into focus, but special attention was also drawn to teachings concerning the afterlife. As a result the ideas nourished in the revivalist movement concerning conversion and the consequences thereof became issues of considerable importance. Although Grundtvig certainly did not sympathize with Visby, he could not avoid noticing a significant divergence between himself and the people of the "godly assemblies," and they likewise must have noticed the divergence.

On July 21, 1831, just as the Visby Case was being closely observed by the public, the third volume of Grundtvig's Christelige Predikener [Christian Sermons] went on sale (even though the year 1830 appears on the titlepage (Bibl. I, 221)). The volume features Grundtvig's largely unaltered sermon from Quinquagesima Sunday 1825 with its extensive and positive treatment of the Descent theme. In one of the few alterations, he expressly defends the conviction that because of Christ's Descent into Hell, pagans and honest truth-seekers had a chance to convert after death. As already 
mentioned, such a conviction was totally unacceptable for the people of the assemblies. A collision seemed to be unavoidable. Grundtvig's stance was firmly rooted in two basic convictions. First, Grundtvig understood Christian baptism as a covenant as opposed to a onesided, forceful imposition. And second, he generally advocated for personal liberty in all spiritual relations; the ungodly must, like everyone, have an option of declining an offer of eternal salvation (see Gregersen 2004, 108; 120-127).

However, Grundtvig chose not to address the Descent issue directly, at least not at this juncture. Instead, he immersed himself in mythological and historical studies and uncharacteristically avoided conflict. Nevertheless, that is what he chose to do. He even avoided mentioning the Descent in a context where it could be expected that he did so. In the above mentioned book from 1832 published in collaboration with L.C. Hagen, he had inserted a poem on the Apostles' Creed. In the second verse, which deals with belief in Christ, he mentions the death of Jesus, his Resurrection and Ascension, but he does not refer to the Descent. Four years later, when the poem was published in 1836 in the first instalment of his great collection of hymns, it was inserted (Bibl. II, 16 and 30).

\section{$1833-34$}

Publication of Nordisk Kirke-Tidende (abbreviated NKt) began immediately after New Year 1833. Like Grundtvig, the editor, Jakob Christian Lindberg, was subjected to censorship. NKt would become a frequent reminder for Grundtvig of the Descent theme.

In the same issue of $N K t$ that announced the publication of Grundtvig's Nordens Mythologi [Mythology of the North], a Norwegian cleric by the name of W.A. Wexels was introduced in highly complimentary words as "this zealous and Christian man" [Denne nidkjære christelige Mand] (NKt 1833, col. 15). Wexels had corresponded with Grundtvig since 1826 and had also contributed to the Theologisk Maanedsskrift [Theological Monthly], of which Grundtvig was co-editor. What was still hidden in the hazy future was that in the mid-1840s Wexels by defending Grundtvig's views on the Descent should become the principal figure in a bitter controversy within the Norwegian church. In the 1830s he was drawn into Lindberg's and Grundtvig's anti-authoritarian circles. 
In the next issue of $N K t$, Grundtvig published an article titled "About the Covenant of Baptism" [Om Daabs-Pagten]. He had been provoked by the fact that the archdeacon at the cathedral of Copenhagen H.G. Clausen had omitted the renunciation of the devil during baptisms. While this article has only an indirect connection with the Descent theme, a next article in the the same issue by the Rev. H.B. Berg went straight to the heart of the matter. Berg accused Clausen not only of intentionally omitting reference to the Descent from his recitation of the Creed, but also of declaring that this omission was merely a minor change. Once again Grundtvig's thoughts focused upon the theological significance, as well as the liturgical status, of the Descent clause in the congregation's declaration of Christian belief.

A later issue of the NKt reprinted W.A. Wexels' extensive report "The Mail-Robber and Murderer M. Petersen" [Post-Røveren og Morderen M.Petersen], which describes how Wexels succeeded in bringing a criminal (Petersen) to repent of his sins and to believe in forgiveness. In the concluding section Wexels references passages from the Bible that later appeared not only in Grundtvig's hymns but also in Lindberg's arguments for the possibility of conversion after death. For example, Wexels mentions Ezekiel 33:11: "As I live, saith the Lord God, I have no pleasure in the death of the wicked" and Luke 23:40-43 about the malefactor on the cross.

At New Year's time 1833-34, Lindberg launched an attack on Professor Niels Lang Nissen, who had characterized the Descent theme as "disgusting" and "offensive." In reply Lindberg outlined the biblical, the Jewish and the Greek-Roman ideas concerning the afterlife, and he attacked scholars who maintained that the Descent was not mentioned by all the ancient Church Fathers. Lindberg points out that the Fathers of course considered the Creed to be so well known that it was not necessary to mention all its constituent elements. And he writes that even Grundtvig writing about the Creed could focus on certain sections thereof without mentioning the preceding and following sections.

At the end of 1834, Lindberg published a series of articles under the heading "Historiske Oplysninger om de gudelige Forsamlinger i Fyen og Sjælland" [Historical information about the godly assemblies in Funen and Zealand]. He mentions a pamphlet written by the peasant Anders Lassen, a member of the assemblies in Gamborg in West Funen. The title of the pamphlet was "Kan Hedningerne blive salige uden Daab og sand 
Christentroe?" [Is it possible for pagans to be saved without baptism and true Christianity]. It had been printed in 1828; Lindberg comments on this article six years later because the question raised in the title was again being eagerly discussed in the community. Lindberg contends that Anders Lassen's arguments are well known, and he adds that the pamphlet does not mention the First Letter of Peter, chapter 3, where the Descent of Christ into Hell and his preaching for those in prison are recounted. This is not problematic, according to Lindberg, because Lassen is well acquainted with the Bible. He writes,

Our [Danish] Bible has almost everywhere neglected to draw attention to the difference between that Hell or Hades to which Our Lord descended and the other, eternal Hell, Gehenna, where the damned are to be punished eternally. The Holy Bible, the Old as well as the New Testament, never confuses these two. But in our Danish translation this difference is not evident, because both concepts are translated by Hell. The difference has also totally disappeared, where Hades is translated by "the Grave." Therefore, the only valid answer to the question raised depends on the correct understanding of the article of faith concerning the Descent into Hell. ${ }^{10}$

Even this thorough reply was not all that Lindberg had to say on the Descent theme.

During the first half of 1835 a comprehensive series of articles, 77 columns in total, all by Lindberg and on the Descent theme, dominated

10 ...vor Bibel-Oversættelse har næsten alle Steder overslettet den bestandige For-

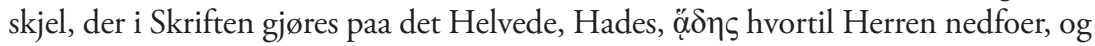

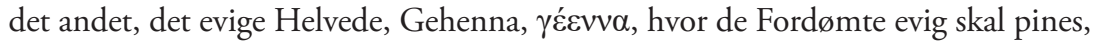
hvilke Udtryk den hellige Skrift, saaavel i det Gamle som Nye Testmente aldrig forvexles, men i vor Bibel-Oversættelse i Almindelighed deels ubemærkelig, fordi begge Udtrykkene ere oversatte ved Helvede, deels virkelig udslettet, hvor Hades er oversat ved Graven. Men af denne Troes-Sætnings rette Opfattelse og Udførelse afhænger ene det gyldige Svar paa det opkastede Spørgsmaal (NKt 1834, Col. 776). 


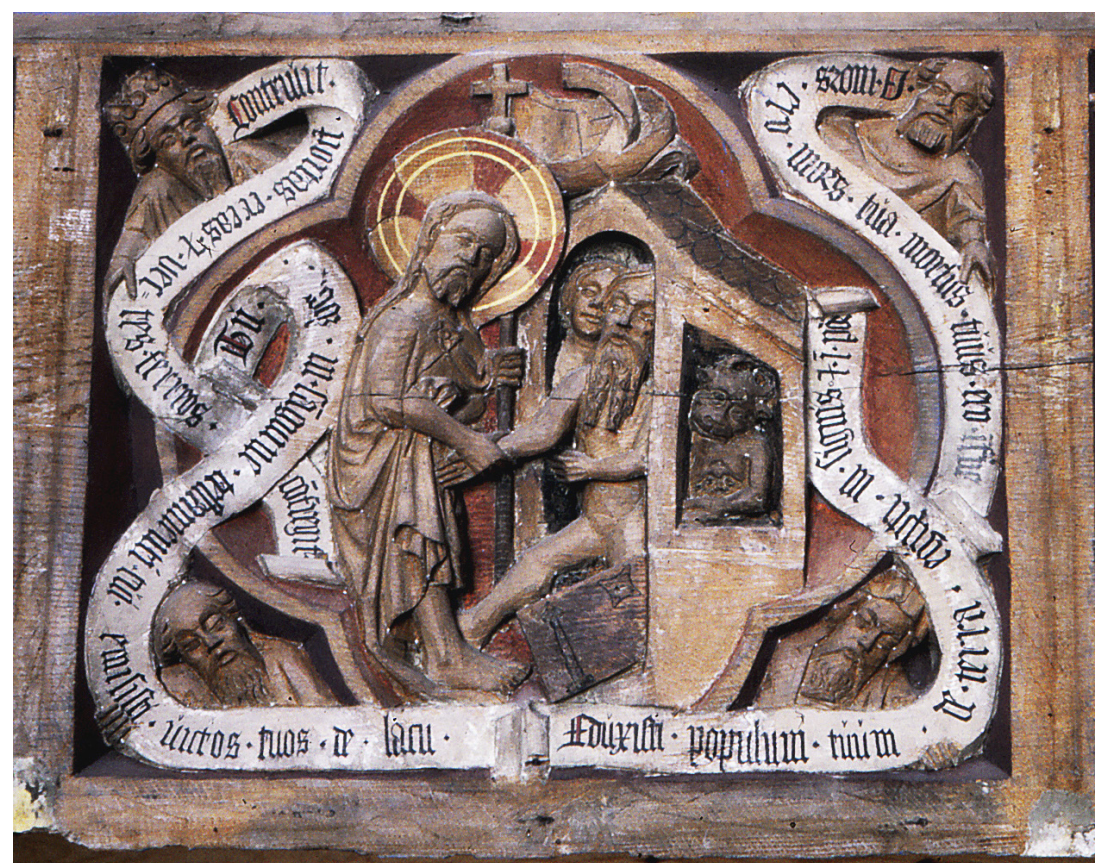

Wood-carving, Roskilde Cathedral, Denmark. 15th century, artist unknown. The original bright colours disappeared after some time but were now and then renewed. Today only few colours remain. The Latin texts quote four biblical passages substantiating the Descent-theme. Reproduced by courtesy of Roskilde Museum.

NKt. Moreover, three further columns were subsequently added, which dealt with "The abyss" and "The Devil's quarter." After an introduction commenting on an article by the Rev. I.H. Edsberg on the Descent, Lindberg makes it clear that several others, e.g.. Grundtvig, have published on this topic. The following sections of Lindberg's treatise appear in the form of seven articles on particular subjects. The last two sections are the most comprehensive. In these seven sections, the main themes are (1) the concept of "Hell" as it appears in the Bible and the Septuagint and Jewish sources and whether it is a place of torment or just a dwelling; (2) the different Danish translations for "Hell" and the "the realm of death"; (3) the conditions of the faithful in the realm of death and the distance between the abode of the saved and the habitat of the wicked, which is "the corner of the devil"; (4) entrance into the realm of the dead and if it takes place 
on the day of individual death, on the Day of Judgment, or at the end of the world; (5) "The Day of the Lord," that is, the Day of Judgment on which all dwelling in the realm of death is terminated; (6) the interpretations of the early church, based on quotations by Irenaeus and Polycarp on the different stages in the underworld and on the growth in faith, as well as citations of and comments upon Tertullian, Hippolytus, Lactantius, Athanasius, Cyril, Hilary, Basil, Chrysostom, Ambrose, and Augustine; (7) the following questions: who were the dead for whom Christ preached? Were they the corporally or the spiritually dead or were they pagans and honest truth-seekers? Does the word "prison" in the First letter of I Peter 3 mean a place of torment or just a temporary dwelling? This section closes with extensive quotations from Eusebius, Ignatius and Hermas Pastor. Lindberg concludes by stating that the purpose of his thorough account has been "to clarify a section of our Christian faith, which overall in the Lutheran church has been overshadowed and neglected by the learned men of faith, so that it is small wonder that it gained only limited importance in the eyes of the faithful." 11

Grundtvig very likely read this extensive treatise; therefore, it may be expected that the reading has left some traces in his writings. Such a trace might be found in his hymn about the Descent, "To Hell our Lord descended" [Til Helvede vor Drot nedfoer], published in his collection of hymns from 1837 (Bibl. II. 30). The first line in the second verse reads "O you article of our faith, which has been so strangely neglected" [Du Ledd af Troen, sært forhadt] (GSV I, 127). As in Lindberg's exposition, Grundtvig speaks about an item of our faith, which has been neglected in the Lutheran tradition. Furthermore, Grundtvig also agrees with Lindberg that this state of affairs is difficult to understand. Grundtvig says "strangely"; Lindberg emphasizes "neglected," when he adds "the learned men of faith."

Thus the possibility exists that Grundtvig read Lindberg's treatise. But we have one more reason for this possibility. The hymn "Hør os, o Jesu, for din Død!” [Hear us, O Jesu, because of your death!] was not included

11 ... at belyse et Led af vor christne Troe, der i hele den lutherske Menighed har staaet i Skygge og været saa stedmoderlig behandlet af troende Skriftkloge, at vi ikke kan undre os over, at den fik saa liden Betydning for de Troende (NKt 1835, col. 318). 
in the collection of hymns published in 1837. It was printed in NKt on the Seventh Sunday after Trinity, which was on the $2^{\text {nd }}$ of August 1835, that is, only two months after Lindberg had concluded his treatise. In the sixth verse we read:

Var Helveds Afgrund end opladt, Even if the abyss of Hell was uncovered Og vilde os opsluge bradt, and would suddenly swallow us up, Fik vi kun Dig i Tale, if only we could exchange words with Thee,

Du gjorde dog, trods Synd og Død, then in spite of sin and death

Os Pinen kort og Sorgen sød,

Thou wouldst make our suffering short and sorrow

Oplod os Himlens Sale. sweet and open for us the halls of Heaven. (GSV I, 127)

We do not know whether Grundtvig sent this contribution to the NKt of his own accord or whether Lindberg encouraged him to. Earlier in the summer of 1835, Grundtvig had made a limited effort to initiate the project of a new collection of hymns. In this phase he rewrote a number of "ancient Danish songs" (Breve II, 246), among which was "O, Jesu, hør mig for din Død." He may, therefore, very well have sent Lindberg a hymn he had just rewritten.

\section{The wider horizons of genesis}

We may now return to the question raised at the beginning of this study: When did Grundtvig write his great hymn I Kveld on the Descent theme? If its genesis could be dated to a certain - relatively narrow - context, then we would very likely also have established when two other poems were written, namely "Kommer, Sjæle, dyrekiøbte" [Come, o souls, who have been dearly bought] and "Himmel-Farten saae i Løn" [The Ascension was mysteriously seen]. In the collection of hymns (1837), they were both published immediately following I Kveld. To both he appended a footnote, as he had done to I Kveld, indicating that they also were inspired by Anglo-Saxon sources (GSVI, 474-475). These three hymns on the Descent theme, therefore, as pointed out by S.A.J. Bradley in his contribution below, constitute a triad. 
The genesis of these three poems might be understood in two broad contexts: first, the years after Grundtvig's encounter with Irenaeus in the 1820 s and, second, the incorporation of the hymns in the general editorial framework of the collection from 1837. Within the structure of these two contexts, we shall focus on the earliest and the latest possibilities.

Theoretically, I Kveld could have been written in connection with Grundtvig's "discovery" of Irenaeus. That is, however, not likely. In 182325 he was immersed in other activities. His renowned poem Nyaars-Morgen [New Year's Morning] (312 verses), was published in 1824. In 1825 and onwards, he had his great theological controversy with H.N. Clausen. From the mid-twenties he was co-editor of and contributor to Theologisk Maanedsskrift [Theological Monthly]. And finally, until May 1826, he had to attend to his clerical duties. In these demanding circumstances, he could also have left the poem in his writing-desk - just as he did not publish his important poem "O deilige Land" [O, thou beautiful land] from 1824. But if so, it could be expected that also the poem I Kveld, like "O deilige Land," would have been included in the 1832-collection co-edited with L.C. Hagen. Finally, he might have published the poem I Kveld in $N K t$ in connection with the incipient debate on the Descent theme. The early possibility of a genesis in the years 1823-25 must, therefore, be ruled out.

The latest possibility is the first months of 1837 , as the poem was printed in the sixth instalment of the hymn collection published during the third week of May 1837 (Bibl. II, 16). However, this timeframe is improbable. During the first months of 1837 Grundtvig experienced his so-called "Greek inspiration," that is, his discovery of and deep fascination with the Greek-Byzantine hymns. This decisive experience began in January when he found the Liturgicon Graece (Venice 1778), which inspired him to compose Danish versions of no less than twenty-four Greek hymns between January and May of 1837 (Elbek 1960, Thodberg 1989). In other words, there was likely no time for an Anglo-Saxon inspiration.

The genesis of I Kveld may also be examined within the framework or general editorial plan of his collection of hymns. Originally, it was Grundtvig's intention to produce a revision of Danish hymns and publish "a collection of old and new" [en Samling af Gammelt og Nyt]. Thus, the primary task was to revise and rework the standard corpus of Danish hymns for publication as the basis of "a collection of old and new" (Breve 
II, 246). He does not mention including his own hymns, it was left an open possibility. Initially, therefore, the focus was on the "old" hymns, supplemented where necessary by new ones. Gradually, as the work progressed, Grundtvig began to develop another, ideological objective to choose hymns that might also serve to represent and characterise the identities of the national Churches or Congregations of universal history, particularly at the times of the great festivals of Christmas, Easter, and Pentecost (Elbek 1960, 7 seq.). He mentions the Anglo-Saxon congregation for the first and second times in the fourth instalment of the collection, published on March 22, 1837, and the third time in the sixth instalment, published in the third week of May 1837. But during the first months of 1837, the above-mentioned all-absorbing Greek inspiration left no elbowroom for serious work with the Anglo-Saxon sources.

On this background we may now consider the possibilities of the year 1836.

\section{$\ldots$ and the more confined}

For Grundtvig and his closest friends, January 1836 was characterized by dejected expectations. In spite of energetic efforts, they had not succeeded in convincing the newly established Advisory Provincial Councils [Stænderforsamlinger] in Roskilde that a more liberal relationship between state and church had to be established. Disappointment and despondency dominate their exchange of letters. In January, Grundtvig describes the Advisory Councils as "The philistines in Roskilde" $(G-I, 179)$. His faithful friend Gunni Busck writes - also in January - that the situation may be likened to walking "in the vale of death" $(G B, 185)$. Grundtvig's depressed state of mind is clearly expressed in a sermon from mid-February, where he writes:

What now? Time passes by, and I may very well say that my days are waning, my corporeal life is in regress. Do I dare to say that my hopes are fulfilled, have I now seen what I expected, or is it coming so near that I have reason to believe that from my heart I soon may say with Simeon "Lord, now lettest thou thy servant depart in peace, according to thy word: For my eyes have seen thy salvation" [Luke 
2,29-30]? The more I preached the gospel, the weaker grew my hope about achieving any obvious result, and in no way did I ever hear about vividly stirring Christianity. ${ }^{12}$

Physically, spiritually, and politically Grundtvig wandered - to use the expression from Gunni Busck's letter - in the valley of death.

In early April, at Eastertime, the situation reverses totally. Grundtvig's writings are now teeming with a new, confident optimism. On Easter Saturday, he informs Busck that he has gained new hope $(G B, 196)$. The reason is a turn of events in the Advisory Councils. By eagerly studying the paper Stender-Tidende [The Advisory Council News], Grundtvig observed two amazing developments: first, that the negotiations were conducted by means of the spoken, living word, which bore witness to "a new accession to the throne of spoken expression" [Mundens Thron-Bestigelse $]^{13}$; and, second, that the Danish people through the provincial assemblies had regained their ancient constitution, which according to the historian Saxo was distinguished by a positive co-operation between "Unrestricted absolute monarchy is the gift of the people and public freedom of speech is the gift of the King" [det uindskrænkede Ene-Herredømme er Folkets og den offenlige Stemme-Frihed Kongens Gave] $(G B, 196)$. Inspired by this discovery, he informs Busck that he has been standing "for two whole months now, as though nailed to the writing-desk, in order to point out this wonder and the natural or historical consequences thereof." [nu alt i hele to Maaneder som naglet til Pulten, for at pege paa det Underværk og paa de naturlige eller historiske Følger deraf] $(G B, 195)$. And he concludes that in due time everything in Denmark will develop according to the identity of the people, just as everything by the grace of God will turn out

12 Men hvad nu? Tiden skrider, ja, jeg maa jo vel sige: Dagen helder, thi mit legemlige Liv gaaer ned ad Bakke, og tør jeg nu sige: mit Haab er opfyldt, har jeg nu seet, hvad jeg ventede, eller nærmer det sig dog saa kiendelig, at jeg har Grund til at troe, jeg snart af mit Hjerte kan sige med Simeon: Herre, nu lader Du din Tjener fare i Fred, som Du haver sagt, thi mine Øine have seet din Frelsning? (...) jo længerre, jeg igien har forkyndt Evangelium, des svagere blev mit Haab om derved at udrette noget Kiendeligt; thi jeg saae og hørde ingenlunde bestandig meer om levende Christendom (GP 9,135).

13 Quotation taken from a contemporary draft, Fasc. 352. 
in a Christian way $(G B, 195)$. The gloomy expectations from January had totally disappeared.

In the same letter of April $2^{\text {nd }} 1836$, Grundtvig tells Busck that he has been extremely busy in matters other than hymns. It was Busck who originally had encouraged Grundtvig to publish a collection of hymns and therefore had an understandable interest in how that project was progressing. Grundtvig can now assure him that the hymns "are not far away" [ikke langt fra] (GB 196). In the preceding two months, he had devoted himself to writing the first book on his new ideas of education, Det danske FiirKlover [The Danish Four-leafed Clover], which was published on May $2^{\text {nd }}$. His declaration in the letter to Busck indicates that he - at the latest at the middle of April - has resumed work on the promised collection of hymns. We do not know exactly when he terminated this hymn-writing period, though it was likely at the end of August. At this juncture he still had not written his preface to the second volume of his World History. An even more demanding obligation was to finish the first instalment of his collection of hymns, which was due to appear at the Reformation-jubilee in October. In this and the following instalment, the focus was on the universal church - not on the national, historical congregations. It is, therefore, not likely that from mid-summer to mid-autumn he had directed his attention towards the Anglo-Saxon poetry. The early summer months of May and June 1836 were more open for that.

From the first half of May, we have a document which seems to be of utmost importance to a search for the genesis of I Kveld, namely Grundtvig's sermon on Ascension Day, May $12^{\text {th }}$. In this sermon he establishes a connection between the Descent of Christ into Hell with his Ascension into heaven. He underscores that both articles of faith are ordained by our Lord, but both are open to misunderstanding. It is, therefore, important to clarify the two concepts. The following clarification that he provides is frequently based on the letters of Paul, and the close link he forges between Descent and Ascension is emphasized:

The Descent and the Ascension are not only as two sections of our Creed equally necessary, but equally important is that these two articles are reciprocally and indissolubly linked together...The Ascension is based on the Descent just as the elevation is on the abasing. This also precisely corresponds to the testimony of Our Lord, that "Who- 
soever shall exalt himself shall be abased, and he that shall humble himself shall be exalted" [Matt 23:12] (...) Thus anything offensive about the Lord's Descent disappears and is replaced by gratitude towards Our Saviour, who did not spare but abased himself as deeply as possible in order to rise to the highest [cf. Rom 8:32] (...) For us this means that Our Lord both descended and ascended for our sake and in our stead, in order that both may be attained and we taken up together with him; and we shall, when the time comes, also bodily share his likeness [cf. Rom 6:5], follow him and share his glory (...)Yes, my friends! He [God] granted Heaven to the children of men, when $\mathrm{He}$ received the Son of Man, who died for us that we may live with him this, unto the end of the world, shall on the day of Christ's Ascension be our thanksgiving hymn. ${ }^{14}$

In this way the sermon not only underscores the close connection between Descent and Ascension but it also clarifies its biblical foundation and finally emphasizes the importance of these events for each individual. The thrust of the sermon is from beginning to end to accentuate the importance of the Descent as formulated in the Creed. The sermon is concluded in praise of the victorious Saviour, whose wish it was and in whose powers it lay to extract "the fruits of salvation" $(G P 9,215)$ for the benefit of his believers.

14 Heraf lære vi nemlig, at Nedfarten og Opfarten ikke blot som to Ledd af vor Troes-Bekiendelse er lige uundværlige, men ogsaa at de To netop indbyrdes er uopløselig forbundne, og at Opfarten netop har sin Grund i Nedfarten, ligesom Ophøielsen i Fornedrelsen, hvad da ogsaa paa det Nøieste stemmer overeens med Herrens eget Vidnesbyrd: hvo som sig selv ophøier skal fornedres, men hvo sig selv fornedrer sig, skal ophøies (...) Herved bortfalder nemlig al Forargelse over Herrens Nedfart til Helvede og afløses af Taknemmelighed til Frelseren, der ikke sparede sig selv, men fornedrede sig det dybeste mueligt for at kunne stige til det Høieste (...) For os [betyder] (...) dette nemlig, at Herren baade nedfoer og opfoer for vor Skyld og i vort Sted, saa at vi kan tilegne os begge Dele, som de der i Aanden er bade opreiste og optagne med ham, og skal, naar Timen kommer ogsaa legemlig ligne og følge ham og dele hans Herlighed (...). Ja, mine Venner! Himlen gav han Menneskenes Børn, da han optog Menneskens Søn, som døde for os, saa vi kan leve med ham, det skal være Lovsangen paa Christi Himmelfarts-Dag til Verdens Ende (GP 9, 214-216). 
Against this background it will be reasonable to assume that Grundtvig wrote the great poem I Kveld either immediately before or soon after this sermon on Ascension-Day. The decisive experience that promoted its genesis is the tsunami-wave of inspiration, which in the months of February and March prompted him to write Det danske Fiir-Kløver. This new optimism, which replaced the depression in January, is then invigorated in April by his preaching on all five Easter-days (cf. GP 9, 67), when his attention was closely directed towards the Easter-events. During the last week of April, when Ascension Day was approaching, his attention turned to the final three stages of the elevation of Christ: Resurrection, Descent, and Ascension. During his preparations for this sermon, he had been able to make use of what he previously had read and was stored in "the archive of his memory" (US I, 17) - all the way from his father's book of catechetical instruction, from the hymns of Kingo, from his Irenaeus-studies, from his Anglo-Saxon inspiration and, at last, from the thorough treatise published by Jacob Christian Lindberg in NKt 1835.

An argument supporting the assumption that the poem I Kveld was written soon after the sermon on Ascension Day, May $12^{\text {th }}$, 1836, is the observation of Christian Thodberg that "the sermon is Grundtvig's theological workshop. In his sermons Grundtvig "writes towards clarity" [his own formulation], i.e. the clarity, we find in the hymns. In other words clarity is found in the hymns, but the background, the presuppositions are found in the sermons" (Thodberg 1989, 140). A genesis much later than the last half of May seems improbable. Only a single reference to the Descent appears in his writings between June to the last half of August. In a June 6 letter to P.A. Fenger, Grundtvig writes, "We know that our redeemer is mighty, for He hath broken the gates of brass and cut the bars of iron" [Ps 107:16] and conquered those, who would lock up his people in corpse-chambers and bone-houses"(Breve II, 263).

The quotation from Psalm 107 in a reference to the Descent appears on a medieval wood-carving preserved in the cathedral of Roskilde (Kürstein 1966, 116, cf. above p. 124). But we have no evidence indicating that Grundtvig should have seen and remembered this carving.

During the summer of 1836 one hears very little about Grundtvig and his activities. He does not contribute to NKt until the end of August. His usually extensive writing of letters is reduced to only two letters (Gr. Reg. $\mathrm{XXIV,172).} \mathrm{A} \mathrm{probable} \mathrm{explanation} \mathrm{is} \mathrm{that} \mathrm{he} \mathrm{is} \mathrm{busy} \mathrm{writing} \mathrm{hymns} \mathrm{and}$ 
concluding the second volume of his World History. Finally, in October the first instalment of Grundtvig's collection of hymns is published. The second instalment came on December $24^{\text {th }}$. The first instalment comprehended the pages 1-96, and the second one the pages 97-192 (Bibl. II,16). The NKt advertised the event by printing a selection of these hymns.

\section{Epilogue in 1837}

The public debate on the Descent was continued in 1837. Grundtvig's follower F.E. Boisen contributed a critical article to the NKt sharply censuring the doctoral dissertation of the Rev. C.H. Vaage on The Descent of Christ into Hell. Boisen's contribution of fourteen columns was published on April $9^{\text {th }}$ and $23^{\text {rd }}$, that is, approximately a month before the poem I Kveld was printed in the sixth instalment of Grundtvig's collection of hymns. Vaage had pointed out that some of the ancient Church-Fathers had not mentioned the Descent. To this argument Boisen retorts that Vaage's point has no weight. That the Descent is unmentioned does not mean that it is unknown or not appreciated. As an example Boisen refers to Grundtvig:

If this [viz. absence of reference to the Descent] could happen with Grundtvig at a time when attention was directed more than ever before upon that clause --and he himself was fighting for the argument that our Baptismal Covenant was corrupted if we, upon our own authority, either took from it or added to it in the slightest, and especially if we omitted the Descent into Hell - then it cannot surprise us if this [viz. absence of reference to the Descent] has happened likewise with many Christians in both ancient and modern times. ${ }^{15}$

Here Boisen refers to Grundtvig's poem on the Covenant of Baptism published in collaboration with L.C. Hagen (1832). In his poem about the

15 Naar dette kunde hændes Grundtvig paa en Tid, da Opmærksomheden meer end nogensinde var henledt paa dette Led, og som selv stred for den Paastand, at vor Daabspagt var forvansket, naar vi paa vor egen Haand enten borttog eller tilføiede det Mindste, og navnligen naar vi udelod Nedfarten til Helvede, da kan det vel ikke undre os, om det er gaaet mange Christne baade i ældre og nyere Tider ligedan (Boisen 1837, col. 297). 
Apostles' Creed, Grundtvig does not mention the Descent (cf. under the above heading 1831-32). In the new collection of hymns from 1837, a correction is made: the third verse acquired an irregular number of lines. Approximately a year earlier, in May 1836, Grundtvig had written I Kveld and two other related poems on the Descent. But that was unknown to Boisen, as that particular instalment of the hymn-collection was not publicly available in April 1837.

In conclusion, it may be observed that Grundtvig's deeply rooted personal understanding of the Descent-theme, which life-experience from the first four months of 1836 had granted him, is expressed directly and indirectly now and then during the following years. It appears, for example, in the hymn "Har vi toppet maae vi dale" [When we have peaked, we must go down] from 1843-45, verse 5, where the expression "the valley of death" is used about human existence. That expression brings the formulation of Gunni Busck from January 1836 to mind. The hymn, which is in tune with Grundtvig's sermon from Ascension Day 1836, concludes as follows:

Aften først, derefter Morgen, Saa den gamle Regning lød, Evig Fryd kun efter Sorgen

Evigt Liv kun efter Død.

Vi maa krybe,

Før vi flyve,

Ned og op gaae Jesu Spor!
Evening first, thereafter morning:

Thus the ancient reckoning ran

Sorrow first then bliss eternal.

Death before eternal life.

Crawl we must,

Before we fly.

Down then up Christ's footsteps go. ${ }^{16}$

\section{Abbreviations}

Bibl. $\quad$ Steen Johansen, Bibliografi over N.F.S. Grundtvigs Skrifter (1948-54) vol. I-IV, Copenhagen, Gyldendal.

Breve I-II Christensen, Georg og Grundtvig, Stener (ed.) (1924-26), Breve fra og til N.F.S.Grundtvig, I-II, Copenhagen, Gyldendal.

16 (GSVIV, 170). Translated by S.A.J. Bradley, November 2014. 
DVI-IV Danne-Virke: et Tidsskrift af N.F.S. Grundtvig (1816-1819), vol. I-IV, Copenhagen, A. Schmidt.

GB Bech, Henr. (1878), Gunni Busck, et Levnetsløb i en Prastegaard, Anden forøgede Udgave, I-II, Copenhagen, Karl Schønberg.

G-I Grundtvig, Svend (ed.) (1882), Grundtvig og Ingemann. Brevvexling 1821-1859, Copenhagen, Samfundet til Den Danske Litteraturs Fremme.

GP Thodberg, Christian (ed.) (1983-86), N.F.S. Grundtvigs Pradikener, vol. I-XII, Copenhagen, G.E.C. Gad.

Gr.Reg. Registrant over N.F.S. Grundtvigs Papirer I-XXX (1957-64), udgivet af Grundtvig-Selskabet og Det Danske Sprog- og Litteraturselskab [edited and published in Copenhagen by The Grundtvig Society and the Danish Language and Literature Society].

GSV Grundtvig, N.F.S (1837), Sang-Vark til den Danske Kirke samlet og lempet af N.F.S. Grundtvig, Copenhagen, Den Wahlske Boghandel.

GSVI-VI N.F.S. Grundtvig (1944-1956), Sang-Verk til Den Danske Kirke, Samlet udgave, Copenhagen, Det Danske Forlag.

NKt Lindberg, Jacob Christian (ed.) (1833-1835), Den Nordiske KirkeTidende, Copenhagen, published by the editor.

PS I-IX Grundtvig, Svend og Christensen, Georg (ed.) (1880-1930), N.F.S. Grundtvigs poetiske Skrifter I-IX, Copenhagen, Gyldendal.

US I-X Begtrup, Holger (ed.) (1904-1909), N.F.S. Grundtvigs Udvalgte Skrifter, Copenhagen, Gyldendal.

VK 1817 Grundtvig, N.F.S. (1817), Udsigt over Verdens-Krøniken fornemmelig $i$ det lutherske Tidsrum, Copenhagen, Andreas Seidelin.

\section{Bibliography}

\section{Works by Grundtvig}

- (1816), Bibelske Predikener efter Tidens Tarv og Leilighed by N.F.S. Grundtvig, Copenhagen, P.H. Schubothe.

- (1816-19), Danne-Virke: et Tids-Skrift I-IV.

- (1817), Udsigt over Verdens-Krøniken fornemmelig i det Lutherske Tidsrum, Copenhagen, Andreas Seidelin.

- (1824), Nyaars-Morgen. Et Rim, Copenhagen. 
- (1827), "Om Legemets Opstandelse og Deel i Guds Rige," in Theologisk Maanedsskrift XI, 1-61.

-(1827-30), Christelige PradikenerellerSøndags-Bog, I-III, Copenhagen, KarlSchønberg.

- (1829), Krønike-Riim til Børnelardom, Copenhagen, Wahlske Boghandling.

- (1832), Nordens Mythologi, Copenhagen, Schubothes.

- (1832), Historiske Psalmer og Riim til Børne-Lardom, Copenhagen, Ditlevsens Forlag.

- (1833), Om Daabs-Pagten, Nordisk Kirke-Tidende, cols 17-25, Copenhagen, J.C. Lindberg.

- (1834), Den Danske Stats-Kirke upartisk betragtet, Copenhagen, Wahlske Boghandel.

- (1834-36), Haandbog i Verdens-Historien I-II, Copenhagen, Karl Schønberg.

- (1836), Det Danske Fiir-Kløver eller Danskheden partisk betragtet, Copenhagen, Wahlske Boghandel.

- (1837), Sang-Verk til den Danske Kirke, Copenhagen, Wahlske Boghandel.

- (1920), N.F.S. Grundtvigs Breve til hans Hustru under Englandsrejserne 18291831. Udgivne af deres Børnebørn, Copenhagen, Marcus.

- (1979), Dag-og Udtogsbøger, edited by Gustav Albeck, I-II, Copenhagen, C.A. Reitzel.

Works by other authors

Allchin, A.M. (1997), N.F.S. Grundtvig. An Introduction to his Life and Work, Aarhus, Aarhus University Press.

Balslev, Peter (1991), Det vingede ord. Om N.F.S. Grundtvigs salmedigtning, Frederiksberg, Materialecentralen.

Boisen, F.E. (1837), "Om Hr. Pastor G.H. Vaages Doctor-Disputats over Christi Nedfart til Helvede," in Nordisk Kirke-Tidende, cols 273-287, 291-304, 305309, Copenhagen, I. C. Scharling.

Bradley, S.A.J. (tr., ed.) (1982), Anglo-Saxon Poetry, London, Melbourne, Toronto.

- (tr., ed.) (2008), N.F.S.Grundtvig. A Life Recalled. Aarhus, Aarhus University Press.

Brix, Hans (1912), Tonen fra himlen: billeder af den kristelige lyrik, Copenhagen, Gyldendal. 
Confessio Augustana (1530), in Den Danske Folkekirkes Bekendelsesskrifter, Oversat og med indledning og noter ved Leif Grane (1976), Copenhagen, Det Danske Bibelselskab.

Elbek, Jørgen (1960), Grundtvig og de greske salmer, Copenhagen, G.E.C. Gad.

Fabricius, Johan Albert (1719), Codex apocryphus Novi Testamenti, 2nd (revised) edition, Hamburg.

Forordnet Alterbog udi Danmark og Norge (1730), Press of His Royal Majesty.

Friis, Oluf (ed.) (1922), A Book of Danish Verse Translated in the Original Meters, New York, American-Scandinavian Foundation.

Gregersen, Niels Henrik (2004), "Guds frie nåde, troens frie gensvar: Frelsens betingelser hos N.F.S.Grundtvig og John Wesley," in Grundtvig-Studier 2004, 103-133.

Grundtvig, Johan (1779), Catechismi Forklaring efter Saliggiørelsens Orden, Copenhagen, Godiche.

Hagen, L.C. (ed.) (1832), Historiske Psalmer og Riim til Børne-Lardom, Copenhagen.

King, Peter (1703), The history of the Apostles creed: with critical observations on its several articles, Oxford, W.B.

Kværndrup, Sigurd (1977), Antologi af nordisk litteratur, vol. 1, Copenhagen, Samleren.

Kürstein, Poul (1966), Korstolene i Roskilde Domkirke og deres billeder, Copenhagen, Høst \& Søn.

Larsen, Anders (1828), Bibelmassig Svar paa det Spørgsmaal: Kan Hedningerne blive salige uden Daab og sand Christendom?, Odense.

Larsen, Henry (1903), Krist og Satan: Nogle Blade af gammel kristelig Digtning særlig hos Angelsakserne (Cadmon), Copenhagen, Lehmann \& Stage.

Liturgicon Grace (1778), Venice.

Ludwigs, Christian (1918), Af Menighedens Sang, Copenhagen, O. Lohse.

Otzen, Benedikt (1984), Den antike jødedom. Politisk udvikling og religiøse strømninger fra Aleksander den Store til Kejser Hadrian, Copenhagen, G.E.C. Gad.

Riegels, N.D. (1781-86), Fuldstandig Kirkehistorie I-III, Copenhagen.

Rønning, F. (1885), “N.F.S. Grundtvig og den oldengelske litteratur," in Maanedsskrift for folkelig og kirkelig Oplysning IV-V, Odense, Miloske Boghandel.

Schjørring, Jens Holger (1990), Grundtvigs billedsprog - og den kirkelige anskuelse, Frederiksberg, Anis. 
Thaning, Kaj (1963), Menneske forst - Grundtvigs opgør med sig selv I-III, Copenhagen, Gyldendal.

Thodberg, Christian (1983), N.F.S. Grundtvigs Pradikener, (Vol. I-XII), Copenhagen, G.E.C. Gad.

- (1989), Syn og sang. Poesi og teologi hos Grundtvig, Copenhagen, G.E.C. Gad.

Thyssen, Anders Pontoppidan (1983), "Grundtvig's Ideas on the Church and the People 1825-47" in N.F.S. Grundtvig. Tradition and Renewal, ed. Christian Thodberg and A. Pontoppidan Thyssen, Copenhagen, Det Danske Selskab, 226-92.

Toldberg, Helge (1947), "Grundtvig og de engelske Antikvarer," Orbis Litterarum V, 258-311.

Toldberg, Helge (1950), Grundtvigs Symbolverden, Copenhagen, Gyldendal.

Wexels, W.A.(1833), "Mine Forhandlinger med Post-Røveren og Morderen M. Petersen", extensive quotations by H.B. Berg in Nordisk Kirke-Tidende, cols 496-511, Copenhagen, J.C. Lindberg. 